\title{
National Synchrotron Light Source Activity Report 2001
}

For the period October 1, 2000 through September 30, 2001

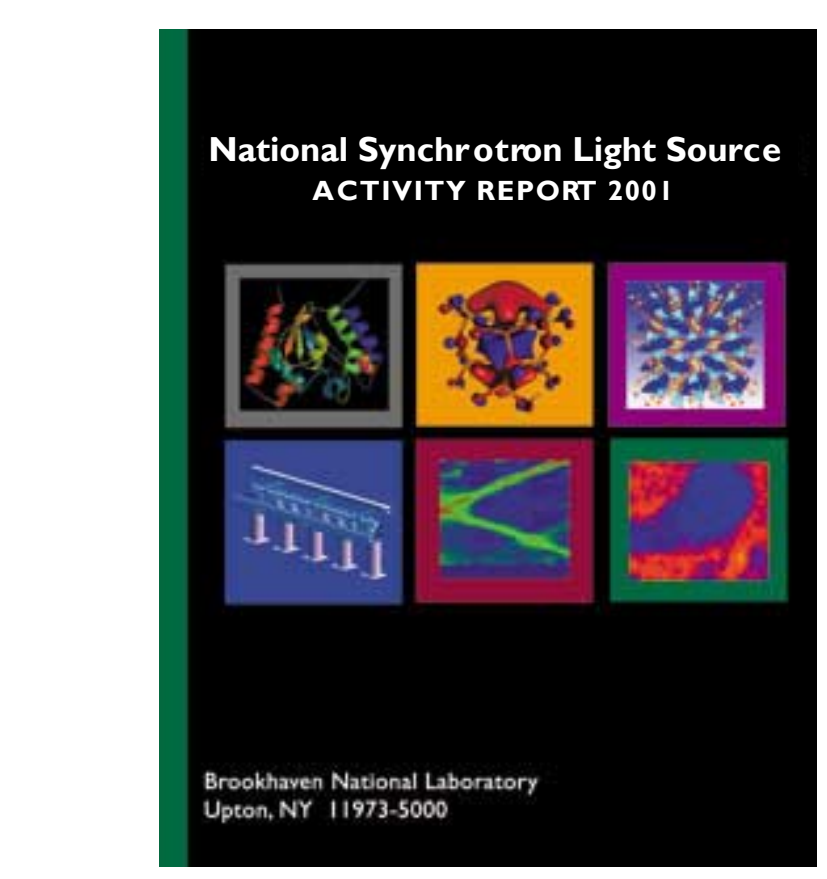

Introduction

Science Highlights

Year in Review

Operations

Publications

Abstracts

Managing Editor

Mary Anne Corwin

Science Editors

Steven N. Ehrlich \& Lisa M. Miller

Production Assistants

Nancye Wright \& Lydia Rogers

The National Synchrotron Light Source Department is supported by the

Office of Basic Energy Sciences

United States Department of Energy Washington, D.C.
Brookhaven National Laboratory Brookhaven Science Associates, Inc. Upton, New York 11973

Under Contract No. DE-AC02-98CH10886

\section{DISCLAIMER}

This report was prepared as an account of work sponsored by an agency of the United States Government. Neither the United States Government nor any agency thereof, nor any of their employees, nor any of their contractors, subcontractors, or their employees, makes any warranty, express or implied, or assumes any legal liability or responsibility for the accuracy, completeness, or usefulness of any information, apparatus, product, or process disclosed, or represents that its use would not infringe privately owned rights. Reference herein to any specific commerical product, process, or service by trade name, trademark, manufacturer, or otherwise, does not necessarily constitute or imply its endorsement, recommendation, or favoring by the United States Government or any agency, contractor, or subcontractor thereof. The views and opinions of authors express herein do not necessarily state or reflect those of the United States Government or any agency, contractor, or subcontractor thereof.

$$
\begin{gathered}
\text { Printed in the United States of America } \\
\text { Available from } \\
\text { National Technical Information Service } \\
\text { U.S. Department of Commerce } \\
\text { 5285 Port Royal Road } \\
\text { Springfield, VA } 22161
\end{gathered}
$$

\section{Cover images}

\section{(clockwise from top left)}

1. from Science Highlight by K.R. Rajashankar, M.R. Chance, S.K. Burley, J. Jiang, S. C. Almo, A. Bresnick, T. Dodatko, R. Huang, G. He, H. Chen, M. Sullivan, J. Toomey, R.A. Thirumuruhan, W.A. Franklin, A. Sali, U. Pieper, N. Eswar, V. Ilyin, and L. McMahan, "Structural Genomics at the National Synchrotron Light Source," page 2-30.

2. from Science Highlight by P. Coppens, G. Wu, C.D. Kim, S. Pillet, I. Novozhilova and W.K. Fullogar, "Excited State Structure by TimeResolved X-Ray Diffraction at the SUNY X3 beamline at NSLS," page 2-55.

3. from Science Highlight by Y. Lee, T. Vogt, J.A. Hriljac, J.B. Parise, and G Artioli, "First Structural Investigation of a Super-hydrated Zeolite," page 2-87.

4. from Science Highlight by K. McCall, A. Lanzirotti, and E.T. Rasbury, "Uranium (VI) Incorporation in Paleosol Calcite: Evidence for Sequestration of Uranium on Geologic Time Scales," page 2-94.

5. from Science Highlight by L. Mihaly, D. Talbayev, and G.L. Carr, "Electron Spin Resonance with Far Infrared Light," page 2-66.

6. from Science Highlight by X.J. Wang, “SASE FEL Saturation Characterization at the ATF," page 2-132. 